\title{
A RESEARCH ON ELECTRICAL ENERGY AUDIT IN AN EDUCATIONAL INSTITUTION -A CASE STUDY
}

\author{
Adjei-Saforo Kwafo Edmund ${ }^{1}$, Adam Misbawu ${ }^{2}$, Ntiamoah-Sarpong Kwadwo ${ }^{3}$, Emmanuel O. Addo ${ }^{4}$, \\ Su Hongsheng ${ }^{5}$ \\ ${ }^{I}$ MSc Student, Department of Electrical Engineering, School of Automation \& Electrical Engineering, Lanzhou \\ Jiaotong University, Gansu, China \\ ${ }^{2}$ Lecturer, Electrical/Electronic Department, Kumasi Polytechnic, P. O. Box 854, Kumasi-Ashanti, Ghana \\ ${ }^{3}$ Head of Department, Electrical/Electronic Department, Kumasi Polytechnic, P. O. Box 854, Kumasi-Ashanti, Ghana \\ ${ }^{4}$ Senior Lecturer, Electrical/Electronic Department, College of Engineering, Kwame Nkrumah University of Science \\ \& Technology, Kumasi- A/S \\ ${ }^{5}$ Professor, Department of Electrical Engineering, School of Automation \& Electrical Engineering, Lanzhou Jiaotong \\ University, Gansu, China
}

\begin{abstract}
Energy, particularly electrical energy is crucial to human sustenance and development. Due to the increasing demand of electrical energy, day by day the gap between the demand and supply is widening, resulting in deficiency in power generation. Bridging these gaps from the supply end is very challenging and exorbitant proposition. Further, limited energy resources, scarcity of capital and high interest costs for the addition of new generation capacity is leading to the increased cost of electrical energy in Ghana. The only achievable way to handle this crisis, apart from the capacity addition, is the efficient utilization of available electrical energy which is only possible by persistently monitoring and controlling the use of electricity. This report seeks to augment energy use awareness, estimate any wastage with the use of appliances and to encourage energy conservative practices in Kumasi Polytechnic. A potential energy savings for lighting equipment, air-conditioners (AC) and computer sets are shown for this study. As an added benefit, these improvements will result in better lighting condition and better controlled classroom temperature-all of which can improve the productivity and general well-being of students and lecturers.
\end{abstract}

Keywords: Electrical energy audit, energy effectual Practice (EEP), lighting equipment, space cooling. $* * *$

\section{INTRODUCTION}

Now-a-days, all of our activities are wholly if not partly dependent upon the use of electricity. Electricity plays important role and serves as the essential ingredient for the industrial and all-round development of any country. It is a coveted form of energy, because it can be generated centrally in bulk and transmitted economically over long distances. Again, it can be adapted easily and efficiently to domestic and industrial applications, particularly for lighting purposes and mechanical work, for example drives. All of us are aware of the various functions that electricity can perform. Thus, it has become part and parcel of our life [1].With the ever increasing per capita energy consumption and exponentially rising population, Ghana is currently undergoing an electricity crisis, popularly known as "Dumsor" [2], which is having a monumentally lousy corollary on individuals, industries and the country's economy in general. Apart from the real causes such as low in-flow of water into the catchment areas of two prominent dams namely; Akosombo and Bui dams, inconsistent flow of gas from Nigeria to power the thermal plants, increment in number of consumers through the activities such as rural electrification projects against the diminishing quantity of electricity the country is already experiencing just to mention few; there has been a deliberate wastage in the system as well as lackadaisically adherent to electrical conservative practices and as a result, landed us into what can be called as an "exorbitant and embarrassing" load shedding exercise since 2006 [3].

Educational institutions like any other reputable firms require energy auditing process due to expansion. In such institutions, the major electrical energy utilizations are normally lighting loads and air conditioning systems. The electrical energy consumption by lighting loads and air conditioners are approximately $20 \%$ and $65 \%$ respectively. Refusal to switch of light when not required to be operated in buildings and surroundings has had adverse effects significantly contributing to the wastage in the system, and this can however be corrected by the use of efficiently designed technology for lighting systems which will not only reduce energy losses but also will improve lumen and lifespan of the lighting systems [4]. Also, the use of efficient air conditioners can reduce wastage and improve the overall efficiency in the system [5]. A case in point is Kumasi Polytechnic which has currently increased its infrastructural development. The management of such institutions spend most of their resources and time in putting up infrastructures such as building of offices, lecture halls, laboratories etc. as well as purchasing equipment, but hardly does management 
make allocation for stimulant economic measures and financial sources for the investment in energy efficient projects and properly prepare energy efficient project proposals, and this however, has landed some of these educational institutions into a wanton amount of debt to pay for tariff. Power supply to Kumasi Polytechnic was disconnected as the Electricity Company of Ghana demanded payment of accrued debt in tariff. The situation brought academic work to a stall whilst security was compromised on campus [6]. The favourable remedial measure to this dilemma, however, is by instituting mandatory periodic energy audits in the various institutions and its likes, in the country which would drastically reduce unnecessary electricity consumption in the National Grid and also significantly downsize energy costs incurred by the institutions over the long term [7]. This has to be accompanied by an inclusive behavioral change of an individuals, information campaign, education and capacity building with the objective to raise the understanding of the significance of energy efficiency and energy management system. As added benefits, these improvements will bring about mitigation of energy cost which is direct profit, reduction of consumption which leads to direct and indirect reduction of environmental pollution and depleting of the natural resources and narrowing demand supply gap [8-11]. Therefore, this paper seeks to address the energy wastage associated with the use of these appliances and recommends appropriate energy saving measures.

\section{ENERGY AUDIT}

An energy audit is a process to reduce the amount of energy input into the system without negatively affecting the output. The term energy audit is commonly used to describe a broad spectrum of energy studies ranging from a quick walkthrough of a facility to identify major problems areas to a compendious analysis of the implications of alternative energy efficiency measures or energy effectual computation (EEC) sufficient to satisfy the financial criteria of sophisticated investors. There are various types of electrical energy audit and the only way to ensure that a proposed audit will meet your specific needs is to spell out those requirements in detailed scope of work. Taking the time to prepare a formal solicitation will further assure the institution or firm of receiving competitive and comparable proposal.

\section{STUDY AREA}

\subsection{Socio-Economic Profile}

Kumasi Polytechnic was established in 1954 to provide high caliber skilled tertiary and middle level manpower with reference to manufacturing, commerce, science and technology and act as a catalyst for technological development. It is one of the famous, elegant and vibrant polytechnics in Ghana. It is spectacularly beautiful institution, which is located at the heart of the Garden City, the capital of Ashanti Region-Kumasi. It has within the period of its existence become an important center for training not only for Ghanaians but also foreigners. It has expanded from three faculties and one center to six faculties, one school and two institutions.

\subsection{Power Distribution System}

Electrical power supply is obtained from indoor mounted distribution transformer which is located in the ground floor of D-Block in the institution. The $11 \mathrm{kV} / 415 \mathrm{kV}$ distribution transformer has HVconnecting armour cable of cross-section $40 \mathrm{~mm}^{2}$ of conductor size. It supplies Asem, Asafo and Amakom environs from consumer distribution units (CDUS).

\subsection{Methodological Approach}

The first phase of the audit is the data acquisition phase of the methodology. In this phase, the acquisition takes place in the form of four steps: the walk audit, document audit, personal audit and technical audit. The data received during data acquisition phase would be compared and interpreted. An electronic format was chosen as the best way to keep records.

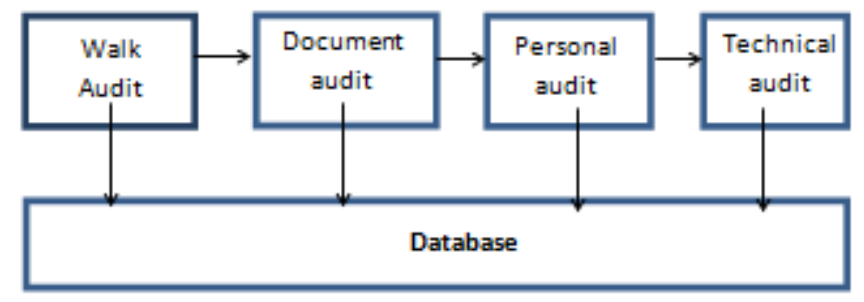

Fig 1(a): The illustration of data acquisition process

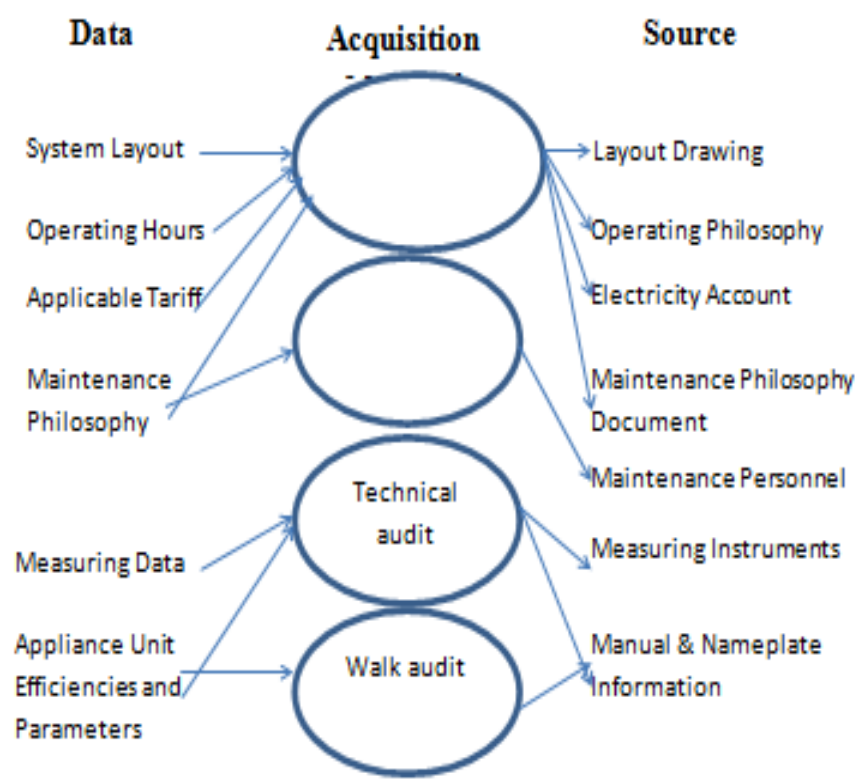

Fig 1(b): The details involved in each acquisition process

\section{OVERVIEW OF DATA COLLECTION AND}

\section{ANALYSIS}

During the year 2015, an electrical energy was conducted in the Kumasi Polytechnic campus to establish the energy utilization profile of electrical equipment in terms of $\mathrm{KWh}$ consumption as shown in the figure 2, 3(a) and 3(b), 
including the cost and hours of operation. The energy audit was conducted for a total average energy utilization of 82 thousand KWh for the selected electrical appliances. It could be seen that energy usage for lighting systems and air conditioners account for a large proportion of the energy consumption, thus having high potential of energy saving. Therefore, the energy effectual computations(EEC) were developed with the sole objective of reducing energy utilization and energy costs in the institution.

\section{Electricity Consumption \\ (Dec-Oct, 2015)}

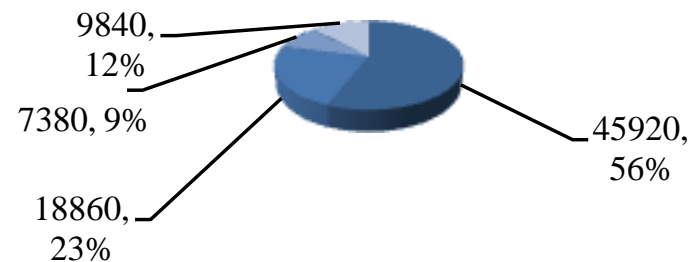

$\square$ Space cooling
$\square$ lighting system
$\square$ Computer \& peripheries
$\square$ others

Fig 2: Monthly Electrical Energy Consumption (KWh) for Space cooling, Lighting System, Computer \& Peripheries and Others.

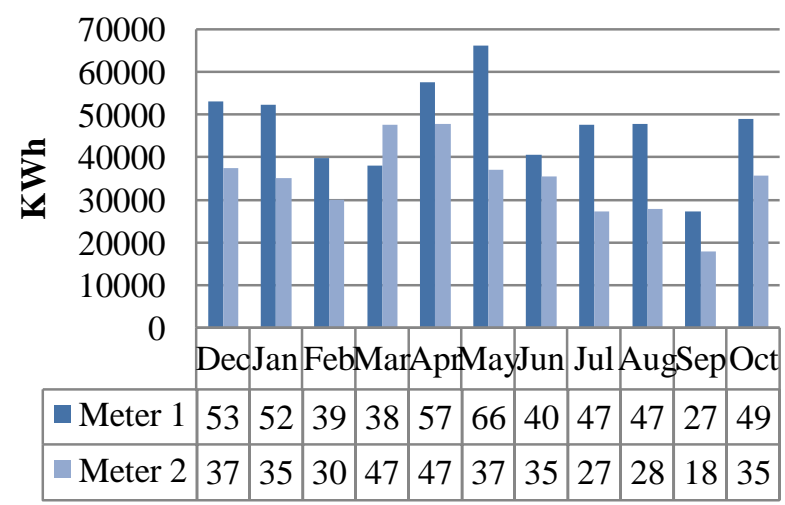

Fig 3 (a):Energy Utilization as well as the Units (KWh) registered by Two Joule Meters installed in the Institution.

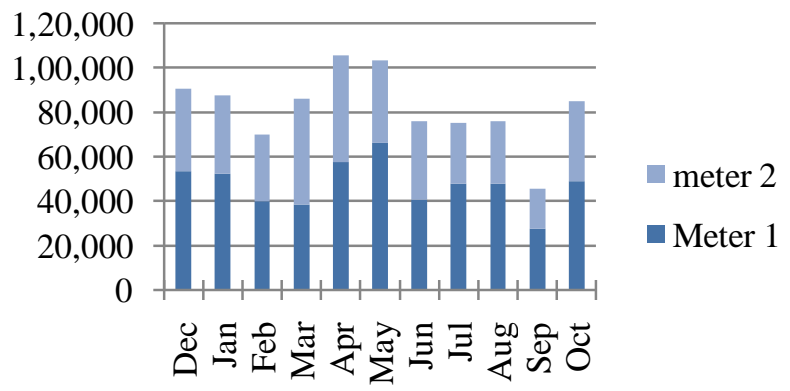

Fig 3(b): Total Summation of Consumed Units (KWh) by Two Installed Joule Meters from December to October, 2015).

\subsection{Lighting Equipment}

\subsubsection{Electrical Energy Audit of Lighting Systems}

The types of lighting equipment used in the institution are fluorescent lamps and high pressure mercury vapour lamps. From the survey conducted, it is clear that there is preponderance of fluorescent lighting both for indoor and outdoor lighting, whilst high pressure mercury vapour lamps are used for streets, gardens, volley ball courts and car park areas. The electrical energy measurement conducted on lighting systems is shown in Table 1 . In compliances with the Illuminating Engineering Society Recommended Practice Guides (IESRPG) and to ascertain the luminance level in different areas of the buildings, lux meters were used to measure lighting levels in the building where there was a presence of (a)both daylight and light (b) only day light and (c) only light. Further, lighting power density (LPD), shown in Table 2, was calculated for some selected areas to find out whether the lighting power allowance (LPA) meet the requirement defined by American National Standards Institute (ANSI), American Society of Heating, Refrigerating and Air-Conditioning Engineers (ASHRAE), and Illuminating Engineering Society of North America (IESNA) [12]. Electrical energy audit conducted on lighting equipment reveals that (1) that some lights were left-on on public place, in rooms and washrooms. Also, many lighting fixtures were connected in single circuit. (2) That there was preponderance usage of inefficient magnetic ballast instead of electronic ballast.

Table 1: Measurement performed on lighting equipment (Feb. $\left.5^{\text {th }}, 2015\right)$

\begin{tabular}{|l|l|l|l|}
\hline Lighting type & No. & $\begin{array}{l}\text { True } \\
\text { power }\end{array}$ & $\begin{array}{l}\text { Rated } \\
\text { Powe } \\
r\end{array}$ \\
\hline $\begin{array}{l}\text { Existing 40 W T12 FTL } \\
\text { with 15 W } \\
\text { electromagnetic Ballast }\end{array}$ & 1127 & $44 \mathrm{~W}$ & $40 \mathrm{~W}$ \\
\hline HPMV & 102 & $253 \mathrm{~W}$ & $\begin{array}{l}250 \\
\mathrm{~W}\end{array}$ \\
\hline
\end{tabular}

Table 2: LPD calculation of selected areas

\begin{tabular}{|l|l|l|l|l|l|}
\hline $\begin{array}{l}\text { Site } \\
\text { Location }\end{array}$ & $\begin{array}{l}\text { Offi } \\
\text { ce 1 }\end{array}$ & $\begin{array}{l}\text { Offi } \\
\text { ce 2 }\end{array}$ & $\begin{array}{l}\text { Walkway } \\
(10 '+w i d \\
\text { e) }\end{array}$ & Lab & $\begin{array}{l}\text { Hal } \\
\text { l }\end{array}$ \\
\hline $\begin{array}{l}\text { ASHRAE } \\
\text { Allowable } \\
\text { LPD } \\
\text { (W/SF) }\end{array}$ & 0.15 & 1.00 & 0.20 & $\begin{array}{l}1.2 \\
5\end{array}$ & $\begin{array}{l}0.2 \\
0\end{array}$ \\
\hline $\begin{array}{l}\text { Actual } \\
\text { LPD }\end{array}$ & 0.05 & 0.8 & 0.08 & $\begin{array}{l}0.5 \\
1\end{array}$ & $\begin{array}{l}0.0 \\
4\end{array}$ \\
\hline $\begin{array}{l}\text { Actual } \\
\text { LPD } \\
\text { Reduction }\end{array}$ & $66 \%$ & $20 \%$ & $60 \%$ & $\begin{array}{l}59 \\
\%\end{array}$ & $\begin{array}{l}82 \\
\%\end{array}$ \\
\hline $\begin{array}{l}\text { Required } \\
\text { LPD } \\
\text { Reduction }\end{array}$ & $20 \%$ & $20 \%$ & $20 \%$ & $\begin{array}{l}20 \\
\%\end{array}$ & $\begin{array}{l}20 \\
\%\end{array}$ \\
\hline $\begin{array}{l}\text { Compl1an } \\
\text { cy }\end{array}$ & YES & YES & YES & $\begin{array}{l}\text { YE } \\
\text { SE }\end{array}$ & $\begin{array}{l}\text { YE } \\
\text { S }\end{array}$ \\
\hline
\end{tabular}




\subsubsection{Energy Efficient Practice for Lighting System}

Electricity utilized by the lighting systems depicts significant proportion of the total consumption of the institution. Therefore to reduce energy wastage and increase energy efficiency opportunities, the following practices must be adopted: Inclusion of reflectors in lighting system fixtures: Reflecting components mirrors light rays uniformly in a given area thereby reducing diffraction and diffusion [13]. This does not only improve the illumination level but also can indirectly reduce number of lamps and consumption when carefully selected. Reduction of the number of lamps: This arrangement is carried out by making comparison of the specifically measured illumination at selected place and the international standardization. For example, taking a tube together with its ballast from each fluorescent fitting, 250 in all, of an open area with sufficient natural light in which the illumination is higher than the standard value can save the institution 43800 unit equivalent to $\mathrm{GH} \varnothing 29,490$ cost savings in a year. Installation of high efficiency lamps: The implementation of these measures will require the replacement of existing 40W T12 fluorescent tubes having electromagnetic ballast with 36W T8 fluorescent having electronic ballast. The electronic ballast which has better energy efficiency also has advantages of high frequency operation which mitigates humming and flickering. Again, the high pressure mercury vapour lamps of $250 \mathrm{~W}$ rating should be replaced with 175 $\mathrm{W}$ rating of pressure sodium vapour lamps. The economic analysis of short term and medium term solution is approximately computed below.

Table 3: Energy Efficiency Practice for Lighting System.

\begin{tabular}{|c|c|c|c|c|}
\hline $\begin{array}{l}\text { Energy } \\
\text { Efficient } \\
\text { Practice }\end{array}$ & $\begin{array}{l}\text { Investm } \\
\text { ent Cost } \\
(G H \phi)\end{array}$ & $\begin{array}{l}\text { Annual } \\
\text { Energy } \\
\text { Savings } \\
(k W h) / y e a \\
r\end{array}$ & $\begin{array}{l}\text { Annual } \\
\text { Savings } \\
(G H \phi)\end{array}$ & $\begin{array}{l}\text { Paybac } \\
k \text { Period }\end{array}$ \\
\hline $\begin{array}{l}\text { Removing } \\
250 \text { tubes }\end{array}$ & Nil & 43800 & 29,490 & Instant \\
\hline $\begin{array}{l}\text { Replacing } \\
\text { electromag } \\
\text { netic } \\
\text { ballast } \\
(15 \mathrm{~W}) \text { with } \\
\text { electronic } \\
\text { type(8W) }\end{array}$ & 4,508 & 14397 & 9,693 & $\begin{array}{l}<1 \text { year } \\
(170 \\
\text { Days })\end{array}$ \\
\hline $\begin{array}{l}\text { Replacing } \\
\text { electromag } \\
\text { netic } \\
\text { ballast } \\
(15 \mathrm{~W}) \text { with } \\
\text { electronic } \\
\text { type(4W) }\end{array}$ & 10,143 & 22624 & 15,233 & $\begin{array}{l}<1 \text { year } \\
(243 \\
\text { Days })\end{array}$ \\
\hline $\begin{array}{l}\text { Replacing } \\
\text { existing } \\
\text { 40W T12 } \\
\text { FTL with } \\
\text { 36W } \\
\text { FTL }\end{array}$ & 24,794 & 19622 & 13,211 & $\begin{array}{ll}< & 2 \\
\text { years } & \end{array}$ \\
\hline Or & 99176 & 34602 & 23,297 & $<$ \\
\hline
\end{tabular}

\begin{tabular}{|l|l|l|l|l|}
\hline $\begin{array}{l}\text { replacing } \\
\text { by Light } \\
\text { Emitting } \\
\text { Diode }\end{array}$ & & & & years \\
\hline $\begin{array}{l}\text { Replacing } \\
\text { HPMV } 25500\end{array}$ & 33288 & 22,412 & $<$ years \\
lamps by & & & & \\
HPSV & & & & \\
lamps & & & & \\
\hline
\end{tabular}

In accordance with table 4, the best energy efficient practice is row 5 which requires replacement of the 40 T12 FTL with LED. Even though the investment cost is extremely exorbitant with less than five years payback period but if implemented could save the institution many Thousands of cedis $(\mathrm{GH} \phi)$ annually.

\subsection{Cooling Space}

\subsubsection{Electrical Energy Audit of Air-Conditioners}

The institution uses both window and split air conditioners. Again, it has a central air conditioning system used in the New Great Hall of the Administration Block. During the diagnostic process, it was seen that the temperature of the chiller was set to $11 C^{\circ}$ but the temperature of the cooled space was about $23 C^{\circ}$; this signifiesthat there is a large amount of air leakage in the building due to lose sealants of windows and doors. Some of the air-conditioners (split and window units) in the building were found oversized. In accordance with literature survey of previous Studies in airconditioners have shown that oversized has a higher peak demand than properly sized ones [14, 15]. Further, low capacity was identified due to (1) low airflow rates, (2) indicative of improper charge of refrigerant, and (3) duct leakages.

Table 4: (a) Performance of $2.15 \mathrm{~kW}$ (3HP) AC in the Machine Lab (Sep. $3^{\text {rd }}-8^{\text {th }}, 2015$ ) (b) Information of central air conditioning system.

(a)

\begin{tabular}{|l|l|l|l|l|l|}
\hline Time (Hour) & $10: 00-$ & $11: 40-$ & $12: 50-$ & $13: 40-$ & $15: 30-$ \\
$11: 10$ & $12: 30$ & $13: 10$ & $14: 30$ & $16: 50$ \\
\hline $\begin{array}{l}\text { Energy } \\
\begin{array}{l}\text { Consumption } \\
\text { (Wh) }\end{array}\end{array}$ & 2532 & 1885 & 372 & 1900 & 1650 \\
\hline
\end{tabular}

(b)

\begin{tabular}{|l|l|l|l|}
\hline $\begin{array}{l}\text { Chiller } \\
\text { Plant No. }\end{array}$ & $\begin{array}{l}\text { Rated } \\
\text { Power } \\
(\mathrm{kW})\end{array}$ & $\begin{array}{l}\text { Capacity } \\
\text { (Tons) }\end{array}$ & $\begin{array}{l}\text { Average } \\
\text { Running } \\
\text { hours/year }\end{array}$ \\
\hline 2 & 202 & 300 & 450 \\
\hline
\end{tabular}

\subsubsection{Energy Efficiency Practice for Cooling Space}

Connecting air-conditioners $(A C)$ to saver switch: Like thermostat, the air-conditioner saver device (ACSD) automatically regulate the cooling cycle (controlling the input power) without affecting its output, typically 10-20 minutes of each half-hour for a period of times depending on 
the equipment. The ACSD device consumption is infinitesimal value; mostly are microwatts designed with advanced micro controller technology and can save up to $30 \%$ of power when included in the AC control circuit. Routine maintenance: An energy efficient practice of airconditioners requires that there must be a scheduled time for maintenance activities. These will include of cleaning the filthy evaporator and chiller, replacement of leakage ducts and sealants. Duct-sealing in a good condition is shown to have saved significant amount of energy for space cooling [16-18]. Properly sizing of air-conditioners : The airconditioner can be properly sized by using Manual Jcalculation [19, 20]. Manual J-method uses climate factors, building physics and characteristics to estimate the cooling capacity need to meet the cooling hours. This method has proved to be worthy and when it is properly applied, it has the tendency to save up to $11 \%$ of energy which can reduce utility peak demand by $26 \%$. [21]

Table 5: Recommended energy efficient practice for airconditioners.

\begin{tabular}{|l|l|l|l|l|}
\hline $\begin{array}{l}\text { Energy } \\
\text { Efficient } \\
\text { Practice }\end{array}$ & $\begin{array}{l}\text { Investm } \\
\text { ent Cost } \\
(\text { GH })\end{array}$ & $\begin{array}{l}\text { Annual } \\
\text { Energy } \\
\text { Savings } \\
(\mathrm{kWh}) \text { year }\end{array}$ & $\begin{array}{l}\text { Annual } \\
\text { Savings } \\
(\text { GH })\end{array}$ & $\begin{array}{l}\text { Paybac } \\
\text { k Period }\end{array}$ \\
\hline $\begin{array}{l}\text { Including } \\
\text { AC saver } \\
\text { switch in } \\
\text { control } \\
\text { circuit }\end{array}$ & 9500 & 18000 & 12119 & $<1$ year \\
\hline $\begin{array}{l}\text { Maintenan } \\
\text { ce of } \\
\text { evaporator } \\
\text { and } \\
\text { condenser }\end{array}$ & 26000 & 32540 & 21909 & $<2$ \\
\hline $\begin{array}{l}\text { Replacing } \\
\text { inefficient } \\
\text { window }\end{array}$ & 160000 & 96570 & 65020 & $<3$ \\
$\begin{array}{l}\text { AC with } \\
\text { energy } \\
\text { efficient } \\
\text { split units }\end{array}$ & & & yays $)$ \\
\hline
\end{tabular}

\subsection{Computer and Its Peripheries}

\subsubsection{Electrical Energy Audit of Computer sets}

The third highest electrical consumption in the institution is computer and its peripheries. The institution has a sum total of thousand and over computer sets in which out of 212 CRT monitors and 804 LCD screens. The average energy consumption performance of various settings is shown in table 6 and figure 4 . The percentage of the existing monitors and CPU with its corresponding mode of operation is also displayed.

Table 6: The performance information of computer set

\begin{tabular}{|l|l|l|}
\hline System & Mode of operation & $\begin{array}{l}\text { Real average power } \\
(\mathrm{W})\end{array}$ \\
\hline \multirow{3}{*}{ CRT } & Off/standby & 2.3 \\
\cline { 2 - 3 } & Active & 70 \\
\hline
\end{tabular}

\begin{tabular}{|l|l|l|}
\hline \multirow{4}{*}{} & Idle & 25 \\
\cline { 2 - 3 } & Sleep & 20 \\
\hline \multirow{4}{*}{ LCD } & Off/standby & 0.8 \\
\cline { 2 - 3 } & Active & 25 \\
\cline { 2 - 3 } & Idle & 15 \\
\hline \multirow{2}{*}{ CPU } & Active & 50 \\
\cline { 2 - 3 } & Idle & 25 \\
\hline
\end{tabular}

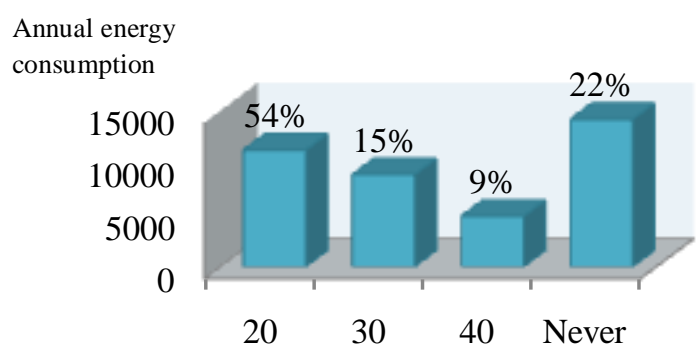

$\square$ Mode of setting for monitors(minutes)

(a)

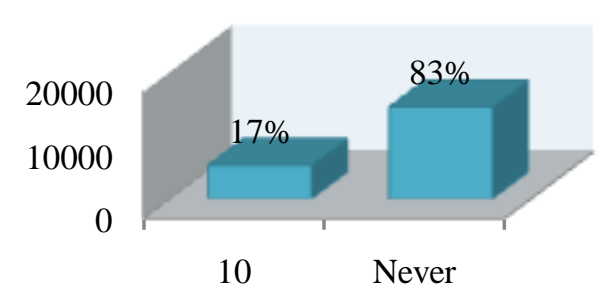

$\square$ Mode of setting CPU (minutes)

(b)

Fig 4: Annual consumption of (a) monitor and (b) CPU with its operative mode.

\subsubsection{Energy Efficiency Practice for Computer set}

An energy efficiency practice recommends: (1) that all CRT's be replaced by LCD's (2) that minimum time settings for turn off monitor's and CPU's are ten and twenty minutes respectively.

Table 6: Recommended energy efficient practice for computer sets.

\begin{tabular}{|l|l|l|l|l|}
\hline $\begin{array}{l}\text { Energy } \\
\text { Efficient } \\
\text { Practice }\end{array}$ & $\begin{array}{l}\text { Invest } \\
\text { ment } \\
\text { Cost } \\
(G H \phi)\end{array}$ & $\begin{array}{l}\text { Annual } \\
\text { Energy } \\
\text { Savings } \\
(\text { kWh }) \text { year }\end{array}$ & $\begin{array}{l}\text { Annual } \\
\text { Savings } \\
(G H \phi)\end{array}$ & $\begin{array}{l}\text { Paybac } \\
\text { k Period }\end{array}$ \\
\hline $\begin{array}{l}\text { Turn off } \\
\text { monitor } \\
\text { after 10 } \\
\text { minutes }\end{array}$ & Nil & 10040 & 6760 & Instant \\
\hline $\begin{array}{l}\text { Turn off } \\
\text { CPU after } \\
\text { 20 minutes }\end{array}$ & Nil & 14500 & 9763 & Instant \\
\hline $\begin{array}{l}\text { Replacing } \\
\text { 212 CRT's } \\
\text { with LCD's }\end{array}$ & 67800 & 38400 & 25854 & $\begin{array}{l}<3 \\
\text { years }\end{array}$ \\
\hline
\end{tabular}




\section{CONCLUSION}

The time has come for educational institutions such as Kumasi Polytechnic to act by taking a leadership role in promoting energy efficiency in the institution by placing higher emphasis on conservative practices, elimination of unproductive and wasteful of power. Significant energy savings are achievable in the institution through the judicious use of electrical energy. The research on the appliances has the potential to save not only energy, but also, to provide the institution with net economic benefits and to reduce sheer waste in the system.

Therefore, if the institution from the chart of quantification by end-users, would implement the measures as directed in this report will save the institution by $15.3 \%$ of consumption for cooling and $11.68 \%$ for lighting and computer sets annually.

\section{REFERENCES}

[1] D. P. Kothari and I. J. Nagrath, "Power System Engineering", Tata McGraw Hill, 2010.

[2] http//www.allAfrica.com "Ghana Electricity Crisis (Dumsor) - The Causes, Disadvantages and Solution.

[3] "The Energy Crisis and Growth Performance of the Economy" Centre for Policy Analysis N0.15, 2007.

[4] W. N. W. Muhamad, M. Y. M. Zain, N. Wahab, N. H. A. Aziz an R. A. Kadir, "Energy Efficient Lighting Design for Building", 2010 International Conference on Intelligent Systems. Modeling and Simulation, 282-286, 2010.

[5] H. E. Hua, L. Tian-yu, Z. Zhi-yong and Z. Juan, "Energy Saving Potential of a Public Building in Jianbei District of Chongqing", International Conference on Management and Service Science, 2009.

[6] http//www.myjoyonline.com/news/2014/November8th/light-out-for-Kumasi-polytechnic-overgh3million-debt.php. "08:50\30.09.15"

[7] S. R. Bhawarkar and S. Y. Kamdi, "Electrical Energy Audit of a Electroplating Unit - A Case Study", 2011 International Conference on Recent Advancement in Electrical, Electronic and Control Engineers, 25-29, 2011.

[8] Arbuthnott D. Katherine "Education for Sustainable Development beyond Attitude Change" Advancing Sustainability in Higher Education, San Francisco: Jossey-Bass, 2007: 37-41.

[9] Abrahamse Wokje, Linda Steg, Charles Vlek and Talib Rothengatter "A Review of Intervention studies aimed at Household energy conservation". Journal of Environmental Psychology 25(2005): 273-291.

[10] McMakin Andrea H., Elizabeth L. Malone and Regina E. Lundgren "Motivating Residents to Conserve Energy without Financial Incentives", Environment and Behaviour 34, No.6 (2006): 848863.

[11] Kahler Shelley "The Ripple Effect of how one Dorm Room can affect a University's Energy Use?"
InternationalJournal of Sustainability in Higher Education 4, No.3 (2003): 230-238.

[12] 'Lighting Power Densities Using the Space-by-Space Method ANSI/ ASHRAE/ IESNA Standard 90.12007" http//www.dpandl.com/bizrebates

[13] "Industrial Assessment Center (IAC). (2001). Industrial Assessment Center Database.Version8.1"http//oipea.www.rutgers.edu/dat abase/db_f.html

[14] P. James, J. E. Cummings, J. Sonne, R. Vieira, J. Klongerbo. "The Effect of Residential Equipment Capacity on Energy Use, Demand and Run-Time" ASHRAE Transaction 103(2) (1997) 297 - 303.

[15] C. Neme, J. Proctor, S. Nadel, "Energy Saving Potential From Addressing Residential AirConditioner and Heat Pump Installation Problems", Rep. No. A992, American Council for Energy Efficient Economy, Washington, DC, 1999.

[16] J. B. Cummings, J. J. Tooley, N. A. Moyer, R. Dunsmore, "Impacts of duct leakage on infiltration rates, space conditioning energy use, and peak electrical demand in Florida homes", in: Proceedings of ACEEE 1990 Summer Study, 1990.

[17] L. Palmiter, P. W. Francisco, "Measured efficiency of forced-air distribution system in 24 homes", in: Proceedings from the 1994 ACEEE Summer Study on Technology Research, Development and Evaluation, 1994.

[18] D. A. Jump, I. S. Walker, M. P. Modera, "Field measurement of efficiency and duct retrofit effectiveness in residential forced air distribution systems", in: Proceedings of ACEEE Summer Study 1996, 1996.

[19] H. Rutkowski, "Residential Load Calculation: Manual J, Air-Conditioning Contractor of America", Arlington, VA, 2004.

[20] A. Rudd, J. Lstiburek, K. Ueno, "UneventedCathedralized Attics Where We've Been and Where We're Going", Rep. no. 9904, Building Science, Somervilla, MA, 1999.

[21] R.G. Lucas, “Analysis of Historical Residential AirConditioner Equipment Sizing", Rep. No. DE93009087, Pacific Northwest Laboratory, Richland, 1993. 